\title{
PERSONAL AND SOCIAL ADAPTATIONS AN INTERVIEW WITH JILLIAN ST. JACQUES
}

\author{
BY LAURENCE RAW
}

Jillian St. Jacques teaches at the College of Liberal Arts at Oregon State University. An adaptation scholar in his own right, his presentations have caused a stir at the Popular Culture Conferences in Albuquerque over the last two years. This interview with Laurence Raw explains why:

$\boldsymbol{L R}$ [Laurence Raw]: Without going into too much detail, how has the experience of adapting to alternative sexualities affected your sense of selfesteem, as well as your perception of identity? Some might say that identity construction is culturally relative, dependent as much on stereotypes as well as societal constructions of what you "should" be. How did you react to such beliefs?

JSJ [Jillian St. Jacques]: My self-esteem has always been fairly solid, so I don't really like myself all that much, so I don't have a lot to fight for. But I also learned that I'd need a lot of self-confidence in order to intentionally walk through life as a transsexual who did not want to pass, because that type of stance generates a lot of psychosexual backlash. When a transsexual seeks to pass as a woman and succeeds, it presents little threat to the heteronormative order. But I was never interested in passing. It was never a possibility for me. What really motivated me was the things I could do with the body at hand: finding out how far I could push my sexual psychological envelope before everything collapsed.

More than twenty years later, having lived as a boy, a man, a transvestite, a transsexual, and a post-transsexual, I resist the notion that discrete sexualities are "alternative," as this implies a normative order of sexuality that does not exist - if there is no norm, there's no alternatives. Reflecting on my childhood, I understand sexuality in a Freudian sense: when children are young they do not consider their sexuality to be alternative to anything. It simply is what it is. Adults are the ones who propose ideas of alterity, which they impose on the child's proprioceptive frame: "here is what your sexuality means, according to the cultural/symbolic structure that surrounds you." But the adult conception of sexual normalcy is arbitrary, based on an ontological lineage of ancestral statements that are not only false but harmful, inasmuch as they impose limits and repressions while being psychologically unsustainable. 
LR: Was the decision to become a transsexual one that took a long time to make? After all, you are laying yourself open to a great deal of potential opprobrium from those around you, even though they might pretend to "understand." Is part of the process of adapting to an alternative sexualities an internal one that has less to do with external and more with internal forces? Can you comment on the relationship between inner and outer, between the public and private selves?

JSJ: My decision to become a transsexual took place gradually and spanned years. At first, I was a rocker-boy from Colorado who moved to a big city (San Francisco) and, in the context of this New Atlantis, I was experimenting with all kinds of things. I was interested in punk rock and glam, so I started crossdressing and doing scary drag things, playing with genderfuck. Also I had lots of encouragement from my lovers at the time - girls and guys who wanted me to dress like a girl, behave like a girl in bed - though there was only so far these lovers were willing to go before the bottom dropped out and they couldn't deal with it, or wanted to go places I wasn't willing to go. But there were always new people to take their place, and if there weren't, there was time to consider what to do next. It was like falling asleep on the midnight bus and waking up in a neighborhood you'd never seen before, except the bus and the passengers kept changing. Eventually I wasn't even in the same town. But each place seemed real enough at the time; I wanted to spread out and experience pleasure there. One doesn't typically choose to become a post-transsexual, after all. They choose to be transsexual first, and then, for whatever reason, they move on. That's a big point for me. You can't move back. The past is sealed. It's forward or nothing.

But back to this question of understanding and adapting. Going to art school also influenced many of the directions my life and sexuality took. As the artist Millie Wilson once pointed out to me, there isn't a big distance between rockerboy and rockergirl, or between rockerboy and glitter-queen. When I moved to San Francisco in the Eighties, there was a legacy of drag troupes like The Cockettes and The Angels of Light, many of whom were dying or had died from AIDS; and I incorporated some of their aesthetic and angst into my own punk aesthetic, first as a transvestite taking hormones and dumpster-diving for clothes, then later as a transsexual with silicone tits working with a performance collaborative, Gender Front, with Joshua Michele-Ross, filmmaker Tanya Stadelman and visual artist Therese Gehri. Over the period of three years, my art, lifestyle, and identity were inseparable, each image shaping the other, and it is from this milieu that I adapted as a male-to-female transsexual role, the position I affiliated with for another decade or so before I moved on. And throughout that "development stage," there were always outsiders urging me to 
adapt one step further. It was like playing a dare game as a child; on a voyeuristic level I am sometimes even loathsome. There are those kids who get vicarious kicks from seeing if you'll go one step further than they can, then laughing when you fall on your ass. American culture's like that: laughing at people when they cannot meet expectations. And since I was always a little kid with a big mouth, I was no stranger to dare games and, for the same reason, I inherently knew people would not be there to pick me up if I fell. If I got hurt badly, I'd have to heal myself. So I was also quite canny with my experimentations; I kept my eyes peeled on the road ahead, even if that road might not be very long (I never expected to live past 30). There were times when things got out of control and I had to pay the price, but I understood the risks up front, and was either scrappy enough or lucky enough to make it through alive. In fact, it was during those times - when people were attempting to kill me or worse through ridiculous dares - that I realized how volatile sexual adaptations can be. Not on a literary level, but on an emotional level. If you mock someone's sexual identity sufficiently aggressively, they will kill you for it. As far as people "understanding" what I was doing, that was never my aim. If someone had sincere questions, I did my best to explain earnestly, even if the questions were boring or predictable, and I felt like I was participating in Gender 101 at school. But if their curiosity was hostile ("don't you realize God thinks you're an abomination?"), I would not be so nice.

But this question of adapting to sexualities is an interesting one, because I do not believe people adapt to anything on a sexual level; they simply acclimatize, which is a completely different thing. Adapting on a subjective level is not possible in light of the fact that we, as individual subjects, are not eternal. Death is the inconvenient truth that precludes that possibility. So there is an endpoint, and whatever we do while we occupy this mortal sexual coil is an acclimatization, not an adaptation, which by definition is a long-distance process that takes place over time. This might seem a small point, but to me it means everything, because I have always seen the libido at the heart of the intellectual enterprise. My point is that sexuality never finds a firm footing anywhere, precisely because the ontological ground on which our individual sexualities are constructed is constantly shifting in reaction to arbitrary forces beyond our control. Societal notions of what is "normal" and "right," our own impressions of our sexual past (which are always open to negotiation and contradiction), representations of sexuality in the media and popular culture, and, above all else, the sudden impact of the unknown. What we thought would be a dull day at our mother's funeral procession suddenly becomes the scene not merely of a crime but our own emancipation. And that's what makes sexuality fun, what makes the libido interesting: it's never static. Like Deleuze's rhizome, it's always on the move, pushing out, pushing up, seeking new avenues and possibilities. I've seen too many people adapt their sexualities when it suited them, when sufficient 
pleasure beckoned from a different direction, and I'm all for that. It's the whole point. If our pleasures become too static, locked down and certain, we become perverts, fixated on the partial objects of our fascination; the same thing again and again without end.

This is not to say that monogamy doesn't have its attractions. I have been monogamous with my current partner for more than twenty years. But within our relationship there are worlds, each of them open, each of them on the move.

LR: The next question is a lengthy one relating to biological adaptation. Once again we have to look beyond what we are told or expected to do or behave, and look instead at the process of personal development, Is/was it a matter of adjusting your psychology to an alternative state of being, or was the process of adjustment comprised of a series of little acts of adaptation?

JSJ: I like the idea of biological adaptation on a sexual level, provided we are speaking about the human race and not me. My patron saint or guiding light or whatever in this direction has always been Judith Butler. Like her, I believe our communal negotiation of pleasure has emancipated a multiplicity of voices into political discourse, and this in turn has re-shaped and revitalized "society" to acknowledge more sexual modes of being. Due to the so called "Sexual Revolution" of the Sixties and Seventies we are seeing deep nuances appear even in sexual subject positions long taken for granted - like fatherhood, motherhood, girlhood - so we now have a place for the queer mother, the queer father, the girl as something beyond silent cypher or troubling minx. In the end, adaptation isn't about sameness, it's about difference - the prominent crest, the use of tools, the multi-pronged tongue, our symbolic relationship with parasites. Species that merely reproduce cannot be said to adapt if they reproduce without variation.

But how does this apply to me on a personal level? At the risk of sounding trite, keeping an open mind about everything is the best approach to survival that necessitates an overall posture of fluidity, the stance best suited for adapting to shifting grounds. At this point in our lives we are no spring chickens ... but we try to stay as intellectually spry as possible. There is nothing more pathetic than the aging scholar whose epistemological frame has become dominated by arcane theories that seem woefully out of date. As the body grows less flexible, we seem to rely increasingly on what we can do with our minds, with the clear certainty that it should have been that way from the start. Increased pleasure demands it. 